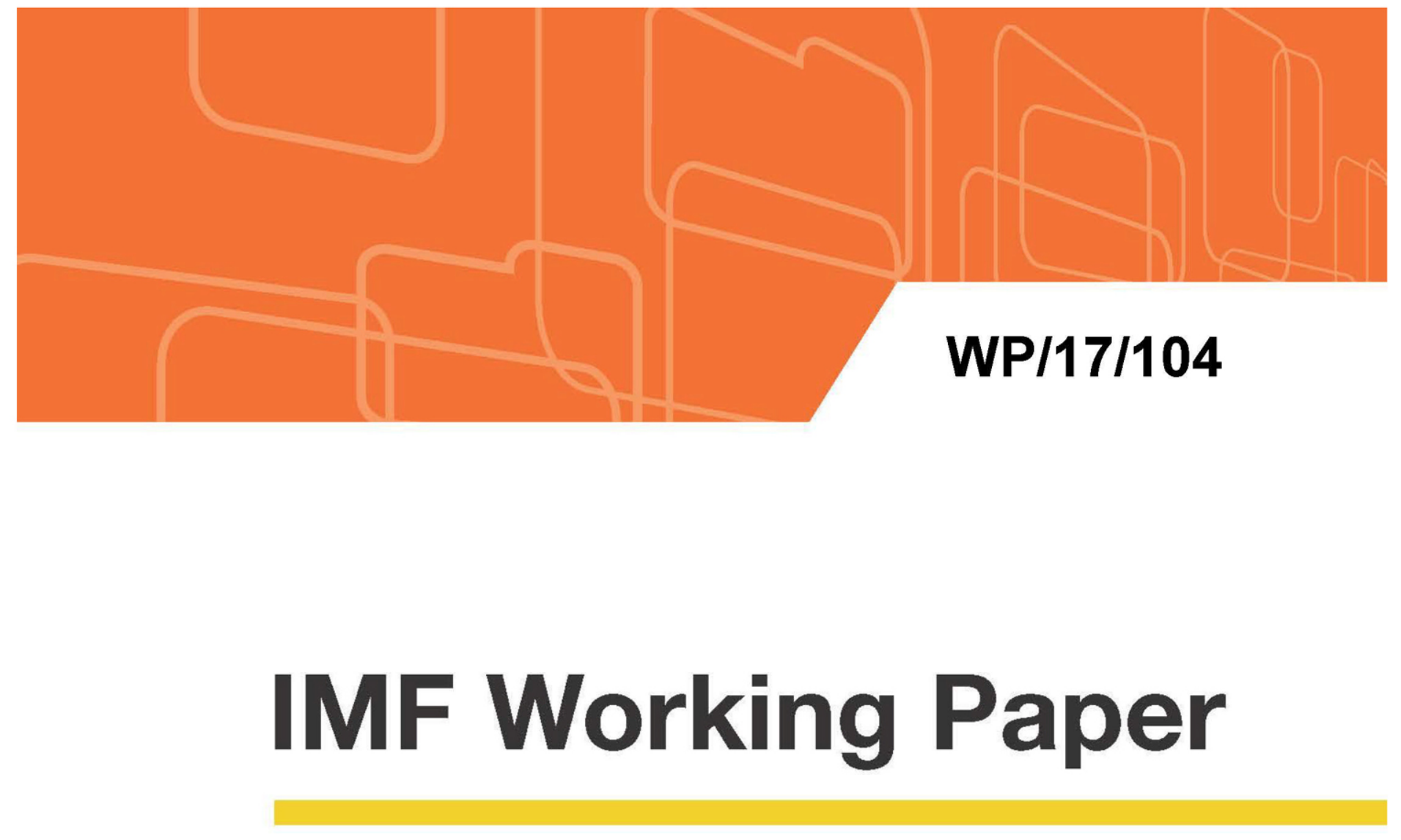

\title{
Taking Stock: Who Benefited from the Oil Price Shocks?
}

by Diego A. Cerdeiro and Dmitry Plotnikov

IMF Working Papers describe research in progress by the author(s) and are published to elicit comments and to encourage debate. The views expressed in IMF Working Papers are those of the author(s) and do not necessarily represent the views of the IMF, its Executive Board, or IMF management. 


\section{WP/17/104}

\section{IMF Working Paper}

\section{Taking Stock: Who Benefited from the Oil Price Shocks?}

by Diego A. Cerdeiro and Dmitry Plotnikov

IMF Working Papers describe research in progress by the author(s) and are published to elicit comments and to encourage debate. The views expressed in IMF Working Papers are those of the author(s) and do not necessarily represent the views of the IMF, its Executive Board, or IMF management. 


\title{
IMF Working Paper
}

Strategy, Policy, and Review, Western Hemisphere Department

Taking Stock: Who Benefited from the Oil Price Shocks?

Prepared by Diego A. Cerdeiro and Dmitry Plotnikov ${ }^{1}$

Authorized for distribution by Lorenzo Figliuoli

May 2017

\begin{abstract}
IMF Working Papers describe research in progress by the author(s) and are published to elicit comments and to encourage debate. The views expressed in IMF Working Papers are those of the author(s) and do not necessarily represent the views of the IMF, its Executive Board, or IMF management.
\end{abstract}

\begin{abstract}
The effect that the recent decline in the price of oil has had on growth is far from clear, with many observers at odds to explain why it does not seem to have provided a significant boost to the world economy. This paper aims to address this puzzle by providing a systematic analysis of the effect of oil price shocks on growth for 72 countries comprising $92.8 \%$ of world GDP. We find that, on net, shocks driving the oil price in 2015 shaved off 0.2 percentage points of growth for the median country in our sample, and 0.17 percentage points in GDP-weighted terms. While increases in oil supply and shocks to oil-specific demand actually boosted growth in 2015 (by about 0.2 and 0.4 percentage points, respectively), weak global demand more than offset these gains, reducing growth by 0.8 percentage points. Counterfactual simulations for the 72 countries in our sample underscore the importance of diversification, rather than low levels of openness, in shielding against negative shocks to the world economy.
\end{abstract}

JEL Classification Numbers: E31, E32, E37, Q41, Q43

Keywords: Oil price, world demand, oil supply, oil demand, output

Authors’ E-Mail Addresses: dcerdeiro@imf.org,dplotnikov@imf.org

\footnotetext{
${ }^{1}$ We are grateful to Roberto Garcia-Saltos, Annette Kyobe, Akito Matsumoto, Robert Rennhack, Marzie Taheri, Bruno Versailles, Alejandro Werner, and various seminar participants for helpful comments. All errors are our own.
} 


\section{Introduction}

The price of oil experienced a dramatic fall between mid-2014 and early 2016. The magnitudes involved are hard to overstate - the drop prompted large redistributions of wealth across countries (see Figure 1), with ensuing changes in investment-savings balances and in exchange rates (see, e.g., IMF (2015a)). The effect that all this has had on growth is, however, far less clear. In particular, observers have been largely at odds to explain why the decline in oil prices does not seem to have provided a substantial boost to the world economy. ${ }^{1}$ This paper aims to address this puzzle by providing a systematic analysis of the effect of the oil price shocks on growth for 72 countries comprising $92.8 \%$ of world GDP.

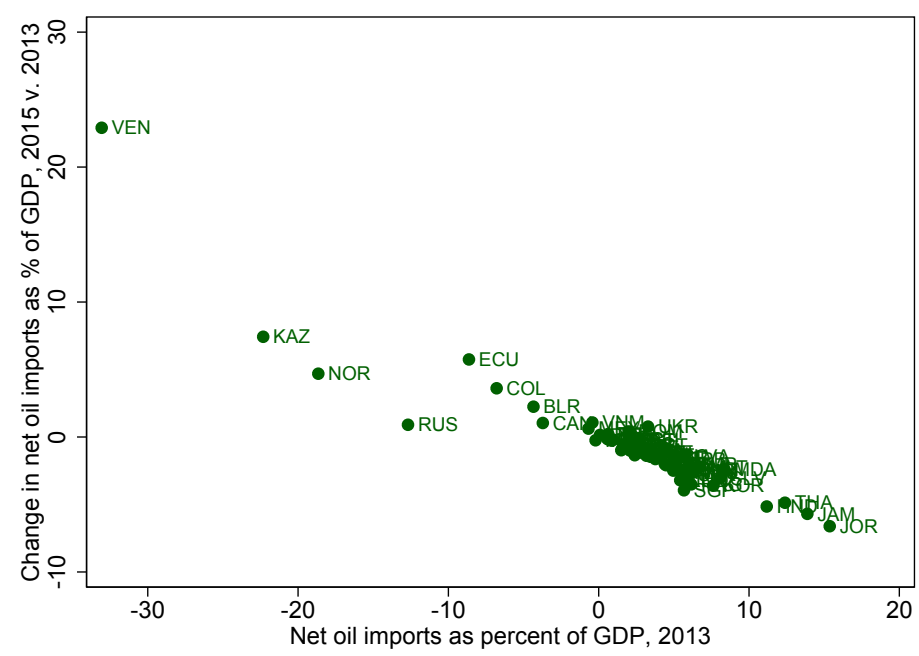

Figure 1: The effect of the oil price drop on current accounts.

The price of oil can move for diverse reasons, not of all which should be expected to have the same effect - in terms of both size and sign - on growth. We use the methodology first proposed by Kilian (2009) to decompose the evolution of the oil price into oil supply shocks, global aggregate demand shocks, and a residual shock. This third shock is orthogonal to the previous two shocks as well as the history of oil supply, world economic activity and the oil price, and in keeping with Kilian (2009) we call it 'oil-specific demand shock.' By combining estimates of these shocks with country-level regressions, we are able to produce counterfactual scenarios of growth in the absence of shocks to the price of oil.

We find that, on net, oil price shocks in 2015 shaved off 0.2 percentage points of growth for the median country in our sample, and 0.17 percentage points in GDP-weighted terms. While increases in oil supply and shocks to oil-specific demand actually boosted

\footnotetext{
${ }^{1}$ See e.g. Obstfeld, Milesi-Ferretti and Arezki (2016) for an interesting discussion.
} 
growth in 2015 (by about 0.2 and 0.4 percentage points, respectively), weak global demand more than offset these gains, reducing growth by 0.8 percentage points. Key to these counterfactual estimates is the relative importance assigned to each of the three shocks in explaining the evolution of the oil price since mid-2014. We find that demand factors global, and in particular oil-market-specific which may be due to expectations of weaker global demand and/or higher global oil production in the future - were important drivers in the oil price decline. In fact, a comparison with previous episodes of large price drops shows that, in the most recent episode, weak demand had a particularly strong bearing on the oil price evolution. Studies that only allow for two shocks (oil supply and demand) typically find a larger contribution of oil supply in the recent oil price decline (e.g. Baffes et al. (2015), IMF (2015b)), thus creating the puzzle of why growth did not respond more positively to the drop in oil prices.

The effects of oil price shocks have been heterogeneous across countries and country groupings. Our estimates indicate that, in 2015, oil price shocks benefited advanced economies, but had large negative effects for emerging markets and developing economies. While oil exporters bore the brunt of the negative effects, the group of oil importers did not benefit from the overall configuration of shocks. This is consistent with the view that the decline in the oil price did not cause positive surprises for oil importers, due to factors including deleveraging in some advanced economies, low pass-through to domestic prices in many emerging markets (including due to balance-sheet repair and subsidies reduction in many state-owned electricity companies), the global effect of the decline in capital expenditure in energy and mining, monetary policy constraints related to the zero lower bound, and heightened geopolitical tensions over this period (Husain et al. (2015), IMF (2016)). In particular, our estimates also show that, since end-2014, the real price of oil has been below its estimated long-term level - significantly so since early 2015. In this context, it is not all that surprising that growth in oil importers has not seen as significant boost (as they save a large part of the windfall). At the other end, liquidity-constrained oil exporters could not smooth out the temporary shocks and were instead forced to adjust. In a further look at the possible determinants of the heterogeneous gains from the oil price shocks (beyond countries' stage of development and net export status), we also find that diversification, rather than low levels of openness, has been important in shielding against negative shocks to the world economy.

Our paper contributes to an extensive literature that aims to understand the effect of developments in the oil market on macroeconomic performance. Most of the earlier studies that estimated the effects of oil price shocks did not consider the composition of these shocks (see e.g. Bernanke, Gertler and Watson (1997), Blanchard and Gali 
(2007)). More recently, the focus shifted towards understanding the role of the different determinants of the price of oil, thus bringing measures of oil supply (Hamilton (2003)), world demand and precautionary demand (Barsky and Kilian (2004)) into the analysis. This approach to understanding the effect of oil market developments on macroeconomic aggregates was systematized by Kilian (2009), who applied it to the case of the U.S. ${ }^{2}$ Our work complements a series of papers studying the effect of oil price shocks at the country level (see e.g. Aslam et al. (2016), Gruss (2014), Aastveit, Bjørnland and Thorsrud (2015), Mohaddes and Pesaran (2016a), Cashin et al. (2012)). ${ }^{3}$ To our knowledge, our paper is the first to present country-level evidence of the effect of the different drivers of the oil price for a very large set of countries. We also provide a simple and sensible approach to estimating counterfactual estimates of growth in the absence of oil price changes, and apply it to all countries in our sample.

The rest of the paper is organized as follows. Sections 2 and 3 describe the methodology and data used, respectively. Section 4 shows the estimates for the world oil market model, including the decomposition of the real oil price into the underlying shocks and an analysis of the stability of the estimates under different subsamples. Section 5 presents the estimated effects on growth for our sample of countries. To understand the effect of the shocks that unfolded since mid-2014 have had on growth, section 6 shows the results of counterfactual simulations. Section 7 concludes.

\section{Methodology}

To understand the effect of oil prices on growth, it is first necessary to identify the underlying forces driving oil price movements. Prices, including those of commodities, move in response to both demand and supply shocks, and the 2014-2016 drop in world oil prices has indeed been related to a combination of different shocks (see e.g. Arezki and Blanchard (2014)).

To identify the underlying (or structural) reasons for oil price movements we follow a simple approach by Kilian (2009). It is based on a structural VAR model on monthly data for the percent change in global crude oil production $\left(\Delta \operatorname{prod}_{t}\right)$, global demand for industrial commodities as measured by an index of world real economic activity $\left(\right.$ rea $\left._{t}\right)$, and the real price of oil $\left(r p o_{t}\right){ }^{4}$ If we let $\mathbf{z}_{t}$ denote the vector of variables of interest,

\footnotetext{
${ }^{2}$ For a detailed survey of the recent literature on identifying oil price shocks, see Kilian (2014).

${ }^{3}$ With exceptions, many of the recent studies do not distinguish between the underlying forces driving the price of oil (or the price of commodities more in general).

${ }^{4}$ It is possible, in principle, to further decompose these structural shocks by country, so that e.g. the effect of an unexpected increase in oil supply by country $x$ can be identified. See Aastveit, Bjørnland and Thorsrud (2015), and Mohaddes and Pesaran (2016a).
} 
$\mathbf{z}_{t}=\left(\Delta \operatorname{prod}_{t}, r e a_{t}, r p o_{t}\right)^{\prime}$, then the proposed structural VAR representation is

$$
\mathbf{A}_{0} \mathbf{z}_{t}=\alpha+\sum_{i=1}^{T} \mathbf{A}_{i} \mathbf{z}_{t-i}+\varepsilon_{t}
$$

where $\varepsilon_{t}$ is a vector of uncorrelated structural shocks, and $\mathbf{A}_{0}$ is a lower-triangular matrix, i.e.

$$
\mathbf{A}_{0}=\left[\begin{array}{ccc}
a_{11} & 0 & 0 \\
a_{21} & a_{22} & 0 \\
a_{31} & a_{32} & a_{33}
\end{array}\right] .
$$

The exclusion restrictions imposed on $\mathbf{A}_{0}$ imply that world crude oil supply does not respond contemporaneously (i.e. within the same month) to global demand shocks or to any demand shock that is specific to the oil market. Global demand, in turn, may respond to contemporaneous innovations in the supply of oil, but not to those specific to the oil market. The real oil price may respond on impact to all three forces. ${ }^{5}$

Directly observable reduced-form residuals, $\mathbf{A}_{0}^{-1} \varepsilon_{t}$, yield the series of structural innovations thanks to the restrictions imposed. Global demand innovations will correspond to those changes in global demand that cannot be explained by past observations and the contemporaneous shock to oil supply. Oil-specific demand shocks - effectively a residual type of shock - are changes in the real oil price not explained by current and past values of oil supply and aggregate demand as well as contemporaneous shocks to oil supply and global demand.

What are oil-specific demand shocks and through which channels do they affect economic activity? As a residual shock, it will capture, inter alia, shocks to precautionary demand for oil, change in global expectations of future aggregate demand or future oil supply. For instance, a technological advance (such as hydraulic fracturing, or fracking) may raise expected future oil supply and thus ease current price pressures. Other channels include, for example, a shift in expected future economic activity that depresses oil prices. Civil conflict or war in an oil-producing country can increase precautionary world oil demand without affecting world economic activity directly, if the country's share of world GDP is small and other oil producers compensate for the reduced oil supply in the country. In all these examples, the price of oil is expected to move despite the absence of observed changes in world oil supply and world economic activity.

\footnotetext{
${ }^{5}$ We have also performed all calculations in the paper changing the order of the first two variables, i.e. having oil supply responding to world aggregate demand contemporaneously. As indicated below, the only noteworthy qualitative difference we find in the results is that, with the alternative ordering, oil supply shocks take effect (on average) faster than world demand shocks (see Section 5). All results with the alternative ordering are available from the authors upon request.
} 
Equipped with the structural innovations that explain oil price movements, we proceed to estimate the effect of these shocks on other variables of interest. Following Kilian (2009), we estimate, for each structural shock separately, a linear regression model where GDP growth $\left(\Delta y_{t}\right)$ is the dependent variable and contemporary and lagged values of the shock are the explanatory variables. More specifically, we estimate

$$
\Delta y_{t}=\alpha_{j}+\sum_{i=0}^{8} \phi_{j i} \hat{\zeta}_{j t-i}+u_{j t}
$$

where $j$ corresponds to each of the three structural shocks, and $\hat{\zeta}_{j t}=\frac{1}{3} \sum_{i=1}^{3} \hat{\varepsilon}_{j, t, i}$ is the quarterly average of the estimated innovations.

A few comments are in order. First, as argued by Kilian, using quarterly averages of the estimated innovations is preferred to estimating the original structural VAR on quarterly data, as in the latter case the identification restrictions would no longer be credible. Second, since the exercise is done at the individual country level, it is sensible to treat shocks affecting the world crude oil market as exogenous. As a result, the coefficient $\phi_{j i}$ simply corresponds to the impulse-response coefficient at horizon $i$, and the number of lags in (2) is set at 8.

Finally, the shocks on the right-hand side of Equation (2) are exogenous from the perspective of any given country. This implies that, while other variables may affect a country's growth in any given period, their exclusion from the model does not lead to omitted variable bias in the estimates of the coefficients $\phi_{j i}$. Including possibly-endogenous explanatory variables, on the other hand, can potentially affect the consistency of those estimates. Because of this, we estimate the parsimonious Equation (2) rather than an equation that, while including a richer set of growth determinants, may undermine identification.

\section{Data Sources}

World oil production data come from the U.S. Energy Information Administration. The global real economic activity index developed by Kilian (2009) is used as indicator of world demand. Monthly oil prices are available since 1968 from the International Financial Statistics database. As in Kilian (2009), the series is deflated using the U.S. CPI. The (monthly) sample for the oil market VAR is 1984:1-2015:12. Figure 2 shows the data used.

The second-step regressions require country-level quarterly real GDP data, which come 

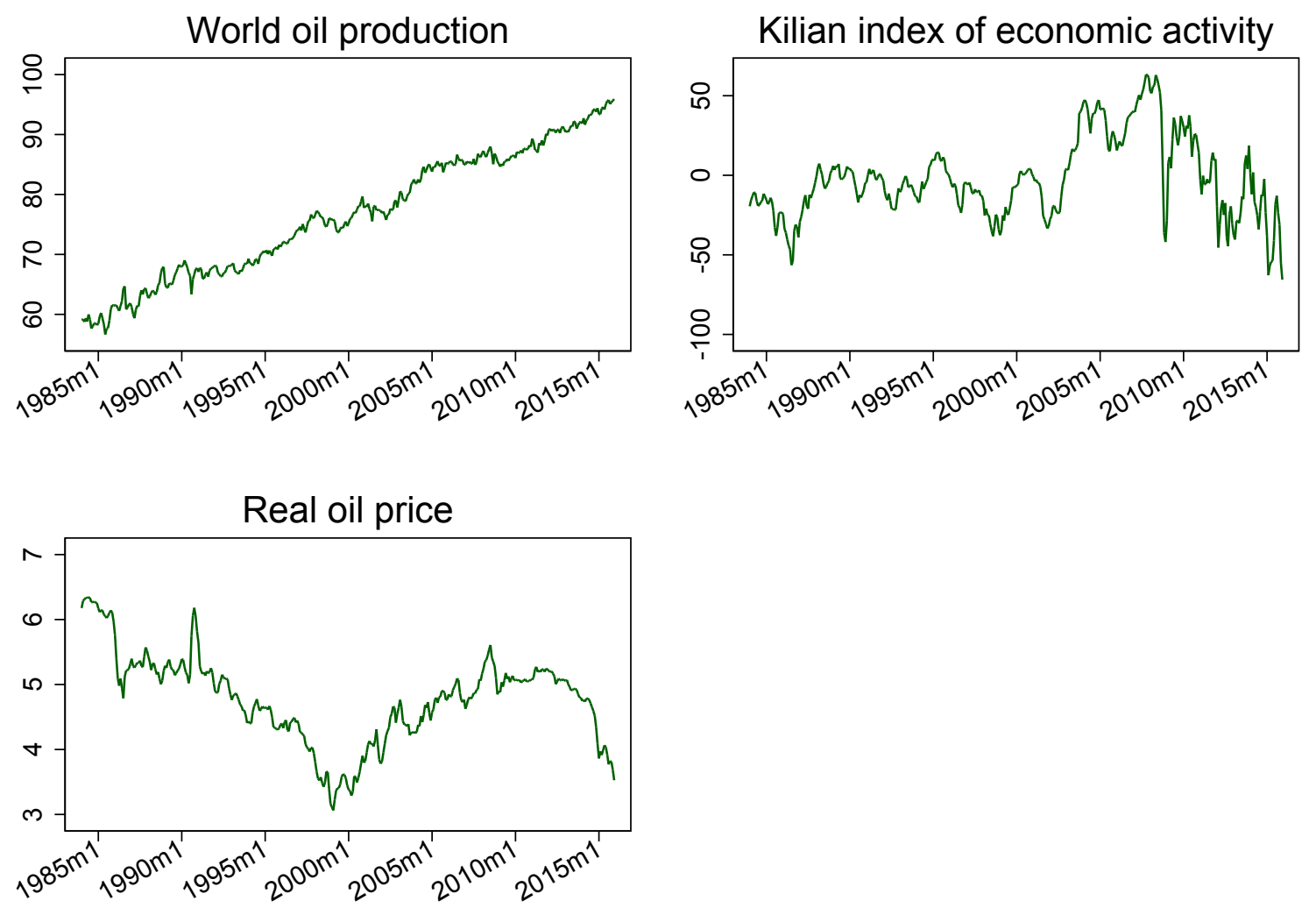

Figure 2: Oil production, economic activity, and real oil price.

from the World Economic Outlook database. Real GDP growth rates are included in the second-step regressions in year-on-year growth terms. Given the possible effect of structural changes in the response to world oil market shocks, all country-level estimates use samples starting in 2000:Q1. Furthermore, we restrict attention to countries having at least 10 years of data (i.e. 40 observations) over the period 2000:Q1-2015:Q4, which leaves us with a set of 72 countries.

The minimum data requirements imposed imply the exclusion of some of the main oil exporting countries from the growth regressions (e.g. Saudi Arabia, Iraq, and Islamic Republic of Iran). It is worth pointing out, however, that the exclusion of these countries from the second step has no implications for the country-level evidence presented here. The reason is that the underlying drivers of the oil price are identified in the first step, which relies on monthly global world market data that aggregates, inter alia, the supply of oil from all oil producers. 


\section{The World Oil Market Model}

Figure 3 shows the response of world oil supply, world aggregate demand, and the real oil price to oil supply shocks, aggregate demand shocks, and oil-specific demand shocks. A one-standard-deviation unanticipated increase in oil supply (equivalent to a one-percent increase in supply) leads to a temporary reversal in production (of about 0.25 percent) two months later, as oil producers around the world react to the surprise. The increased supply of oil leads to a peak decline in its real price of about $2 \%$ within $3-4$ months that slowly fades out over a 3-year horizon. The effect of this shock on world demand is not statistically significant.

Aggregate demand shocks are highly persistent, with their effect on world economic activity dying out slowly over three years. Oil production increases in the following months as a response. The real oil price steadily increases, and only begins to decline after 18 months. Unexpected increases in demand specific to the oil market have long-lasting effects on the real oil price, although the impact peaks within the first six months. These shocks also spur a temporary increase in world economic activity. There is no statistically significant effect on oil production.

Our estimates of the world oil market model are somewhat different from Kilian (2009). Differences between both sets of estimates stem primarily from the sample periods considered in each case: 1973:M1-2007:M12 in the case of Kilian (2009), 1984:M1-2015:M12 in our case. That is, while Kilian's results reflect responses to events of the world oil market during the 70s and early 80s (including e.g. the oil supply disruptions of the late 70 s), our results incorporate the system's responses to the post-global financial crisis oil market shocks. Contrary to Kilian, our estimates show significant effects on the real oil price due to structural shocks to oil supply. This may partly reflect that, in the more recent past, and consistent with the declining importance of OPEC, unexpected increases in oil supply in one region have not necessarily been met by cuts in other regions. ${ }^{6}$

In order to understand the structural shocks' contribution to the evolution of the (log) real oil price, Figure 4 shows the historical decomposition starting in January $2000 .^{7}$ The Figure identifies a cycle lasting just over a decade, with the real oil price above its longrun trend between 2004 and 2014. ${ }^{8}$ Starting in late 2014, the real price of oil has been

\footnotetext{
${ }^{6}$ The shift in OPEC's role was reflected, for example, in Saudi Arabia's decision not to cut its production as the oil price tumbled in the second half of 2014. See e.g. "Why Saudis Decided Not to Prop Up Oil," The Wall Street Journal, December 21, 2014 (retrieved October 18, 2016).

${ }^{7}$ The data are shown as deviation from the long-run real oil price. Let $r p o_{l r}$ denote the long-run real oil price. The solid black line in Figure 4 depicts $\ln \left(r p o_{t} / r p o_{l r}\right)$. Thus, for example, the December 2015 value of -0.9 (last data point) means that the real oil price was estimated to be about 60 percent below its long-run level $\left(r p o_{t}=\exp (-0.9) \times r p o_{l r}\right)$.

${ }^{8}$ The start of this cycle broadly coincides with those identified in analyses of commodity prices over
} 


\section{Responses to one-standard-deviation orthogonalized shocks 70 percent confidence intervals}
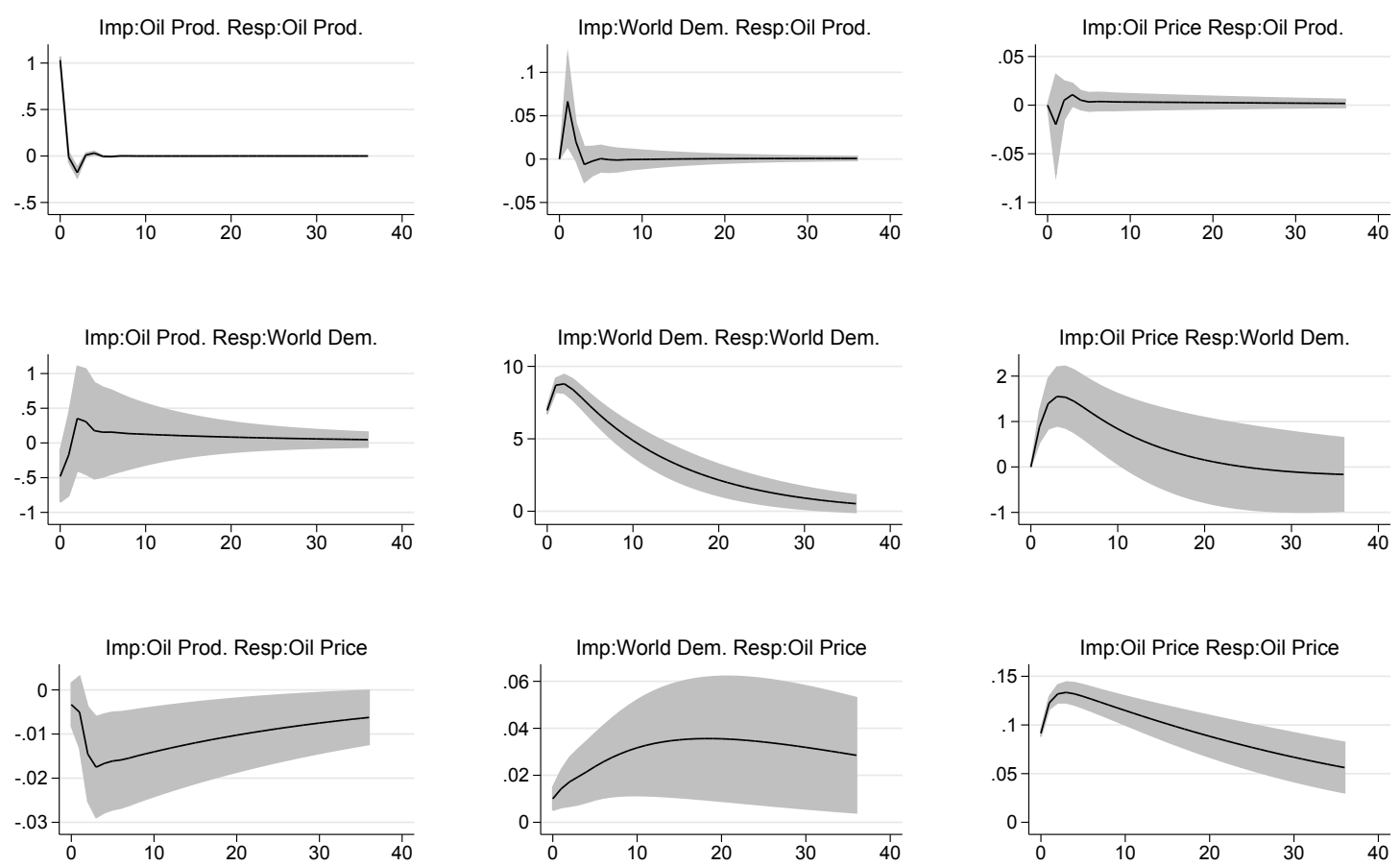

Figure 3: World oil market model.

below its estimated long-term level - significantly so since early 2015. World demand was a key driver behind the increase in the real oil price since early 2003 up to the global financial crisis. After having a negative effect on the oil price during the peak of the crisis, the influence of aggregate demand shocks was mostly neutral through 2011. The effect of aggregate demand has since then been largely negative. The influence of oil supply shocks has been typically smaller than that of aggregate demand, in line with empirical evidence that oil supply shocks have only modest effects on the oil price (Kilian (2014)). The plateau in oil supply between 2004 and early 2009 pushed up the real oil price. Since then, and particularly from 2013 on, the increase in production has had a small but increasing negative influence on prices.

The sharp drop in prices at the end of 2014, however, is mostly due to the negative effect of demand shocks specific to the oil market. This is consistent with evidence that shifts in expectations about future excess oil supply can have sizeable price implications (see e.g. Kilian and Murphy (2014), and Beidas-Strom and Pescatori (2014)). Realizations about increased future shale oil production, or about the ability and willingness of OPEC longer time periods (Erten and Ocampo (2013), Jacks (2013)). 


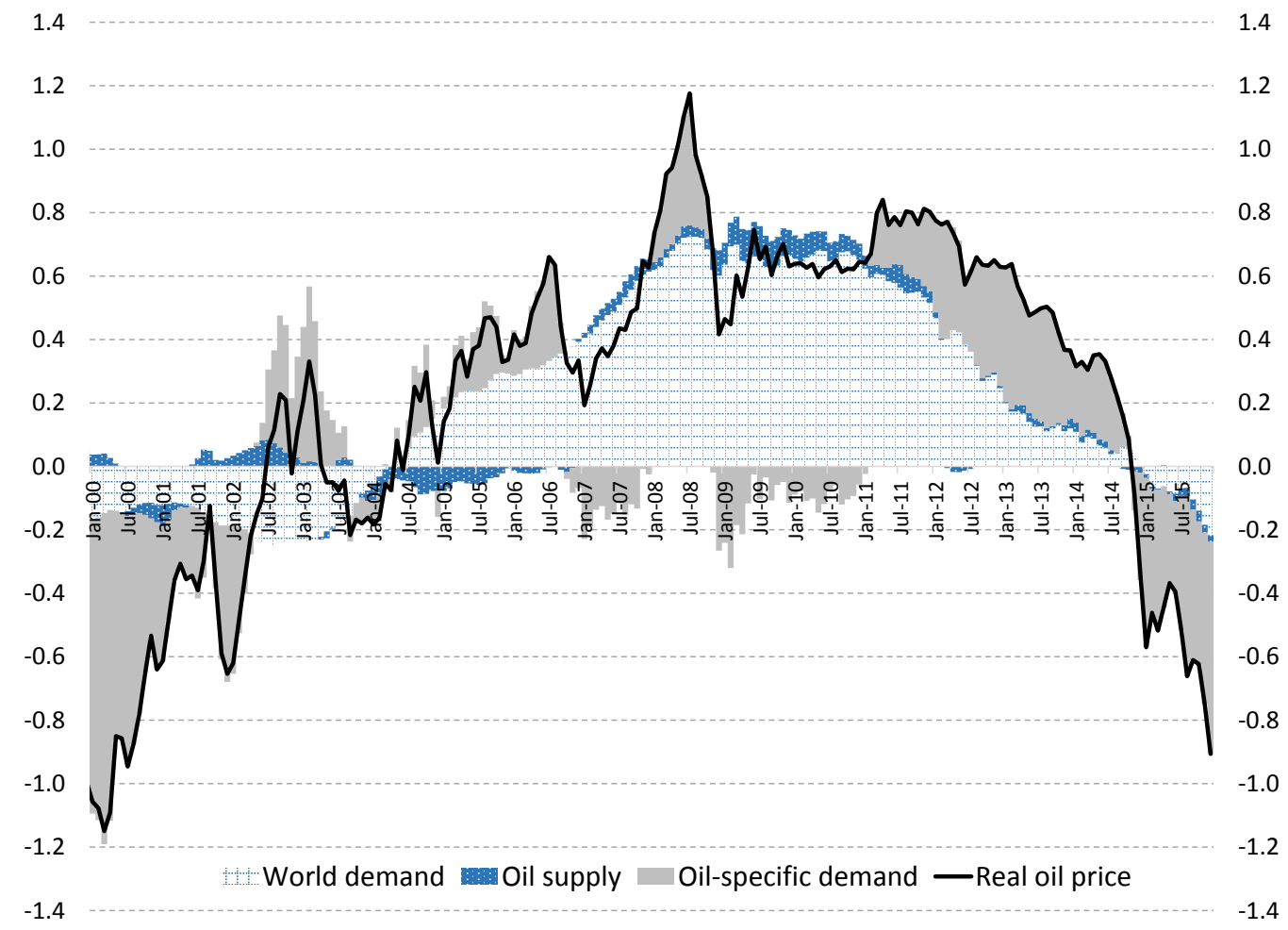

Figure 4: Historical decomposition of the demeaned logarithm of real oil price into the three structural shocks: oil supply, aggregate demand, and oil-specific demand.

producers to restrict oil supply in the future, may explain a large fraction of the recent oil price slump.

The recent decline in the price of oil is, to be sure, not entirely unprecedented (Baffes et al. (2015), Mohaddes and Pesaran (2016b)). Figure 5 shows the relative magnitudes of these price drops, alongside the corresponding contribution of world aggregate demand. ${ }^{9}$ Two features stand out in this historical comparison. First, that the decline in the real price of oil observed observed between July 2014 and December 2015 is - at $1-\exp (-1.2)=70 \%$ - the largest of all those considered. Second, that weak world aggregate demand appears responsible for a relatively large part of the decline. The only other episode where world demand explained a larger share of the price change (May-November 2001) corresponds to a much smaller real oil price decline. This feature alone at least

\footnotetext{
${ }^{9}$ The first five episodes in Figure 5 are the same as those considered in Baffes et al. (2015) (Figure 1). The last episode, which is the period for which counterfactual simulations are produced below, is longer than the one considered by Baffes et al. (2015) (who focus on July 2014-January 2015).
} 


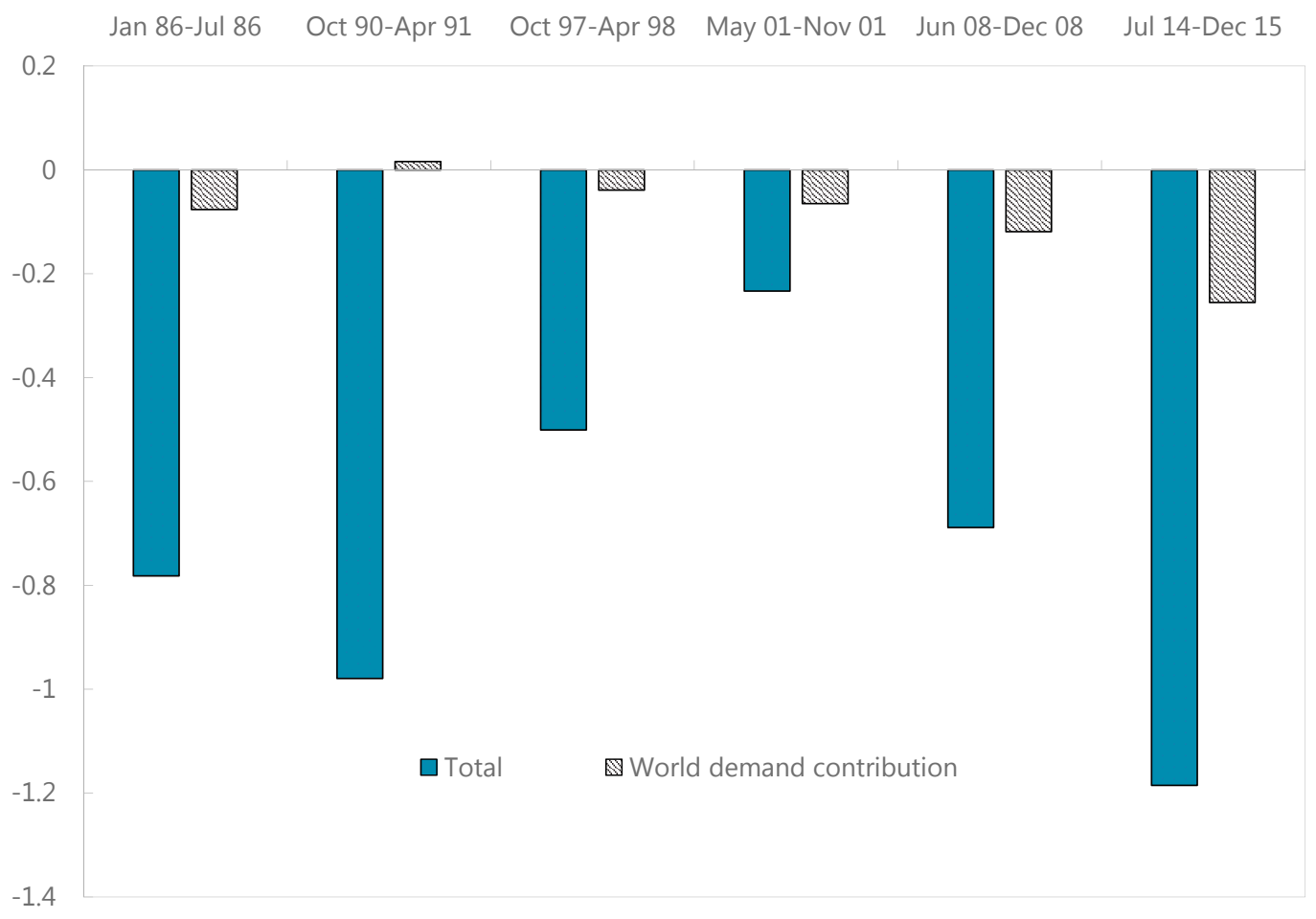

Figure 5: Log-difference of real oil price in six in-sample episodes of sharp price declines.

partly explains why, compared to previous episodes, the most recent oil price drop may not have generated a stronger growth boost in many countries.

\subsection{Stability of estimates}

Considering the increased contribution of shale oil in global oil supply, the implicit assumption of constant parameters is worth discussing. Of particular interest is whether the so-called 'shale revolution' has led to significant changes in estimated coefficients.

In all, the VAR model is composed of nearly 30 coefficients, ${ }^{10}$ and gauging overall stability is difficult if all coefficients are to be considered separately. A feasible and meaningful check of estimates' stability can rely on the cumulative long-run effects of the structural shocks on each of the three endogenous variables. This is captured by matrix $\left(\mathbf{A}_{0}-\mathbf{A}_{1}-\mathbf{A}_{2}\right)^{-1}$. Figure 6 plots the estimates of this matrix under different samples, where the start date changes and the end date is fixed at December 2015. The estimates

\footnotetext{
${ }^{10} 18$ lagged coefficients, 6 contemporaneous coefficients, and 3 intercepts.
} 
range from those of the baseline sample presented above, i.e. the full sample that starts in January 1985, to the sample that starts in January 2005. This shortest sample aims to cover the period of the shale revolution, which started in the mid-2000s (see e.g. Kilian (2016)).

The estimates appear to be generally stable. In particular, we note some variability in the estimates when data from the late-1990s drop off the sample - both in the response of oil supply and world aggregate demand. Interestingly, however, estimates mostly return to their previous levels once data from the early 2000s are dropped from the sample. Thus, while estimates differ slightly under different subsamples, the evidence presented here gives us some degree of confidence about the usefulness of the model to understand the oil market dynamics over the more recent period.
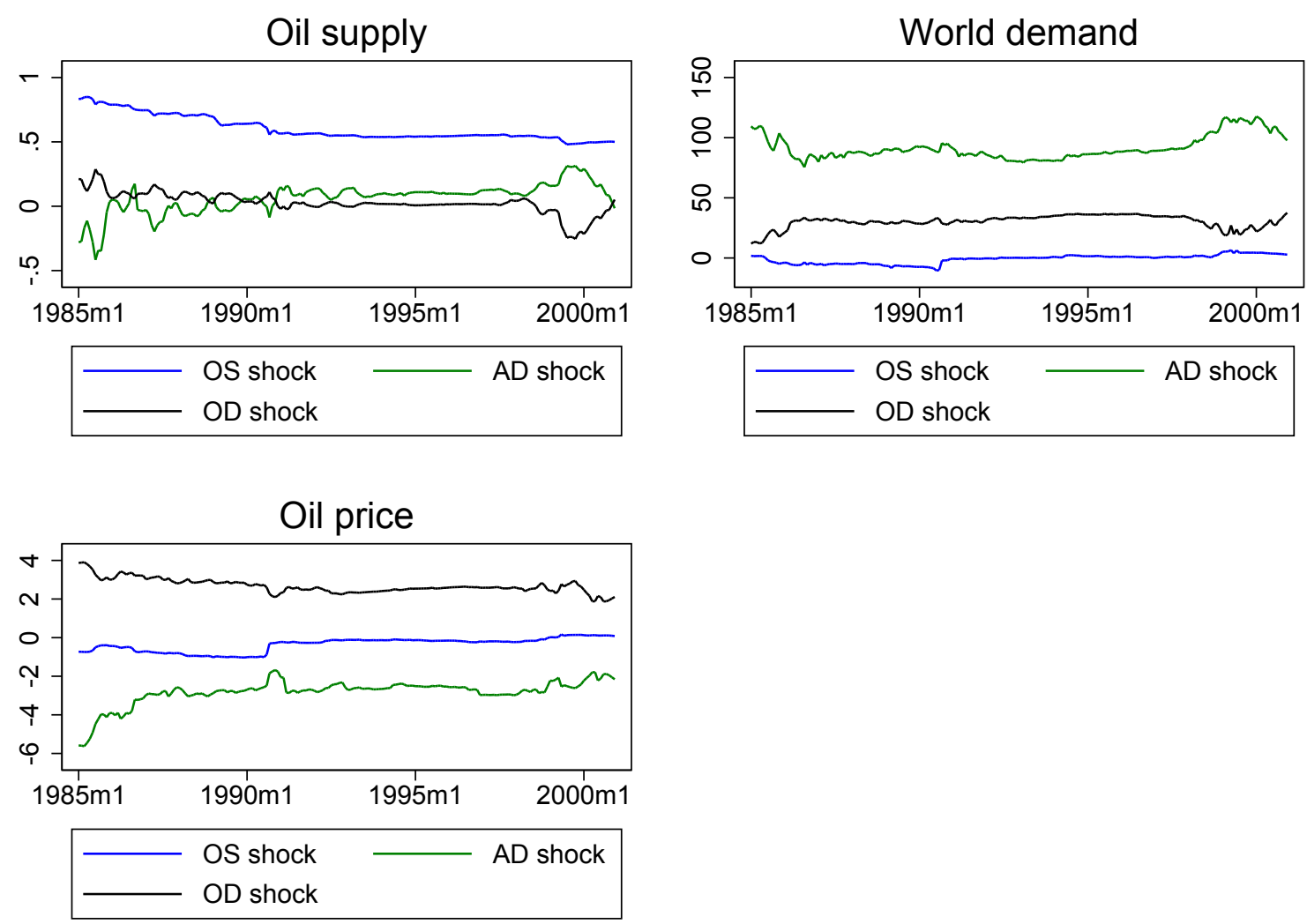

Figure 6: Stability of estimates. Each panel shows the corresponding row of the estimate of cumulative long-run matrix $\left(\mathbf{A}_{0}-\mathbf{A}_{1}-\mathbf{A}_{2}\right)^{-1}$. The date on the horizontal axis marks the starting date of the sample. All samples end in December 2015. 


\section{Growth Estimates}

This section presents the results from estimating the growth Equation (2). Figure 7 shows the cumulative growth responses to each of the three structural shocks from impact through the subsequent four quarters. The responses to shocks specific to the oil market, i.e. oil supply (top-left panel) and oil-specific demand (bottom-left panel) shocks, are plotted against countries' net oil balance. The response to world aggregated demand shocks (top-right panel) is shown against countries' openness measured as the ratio to GDP of the sum of their exports and imports of goods and services.

Oil supply shocks tend to have a positive effect on growth for net oil importers, that may benefit through better terms of trade. The effect on net oil exporters tends to be nonsignificant, except for a few countries that benefit from the higher production volumes. Aggregate demand shocks also tend to benefit all countries. With some exceptions, the effect of world demand shocks is on average stronger in more open economies. Some relatively closed economies (such as Venezuela, Russia, or Brazil), benefit strongly from world demand shocks due to their large share of commodity exports. In all, the cumulative growth effect that an aggregate demand shock can have on annual growth ranges between about 0.1 percent to nearly 3 percent.
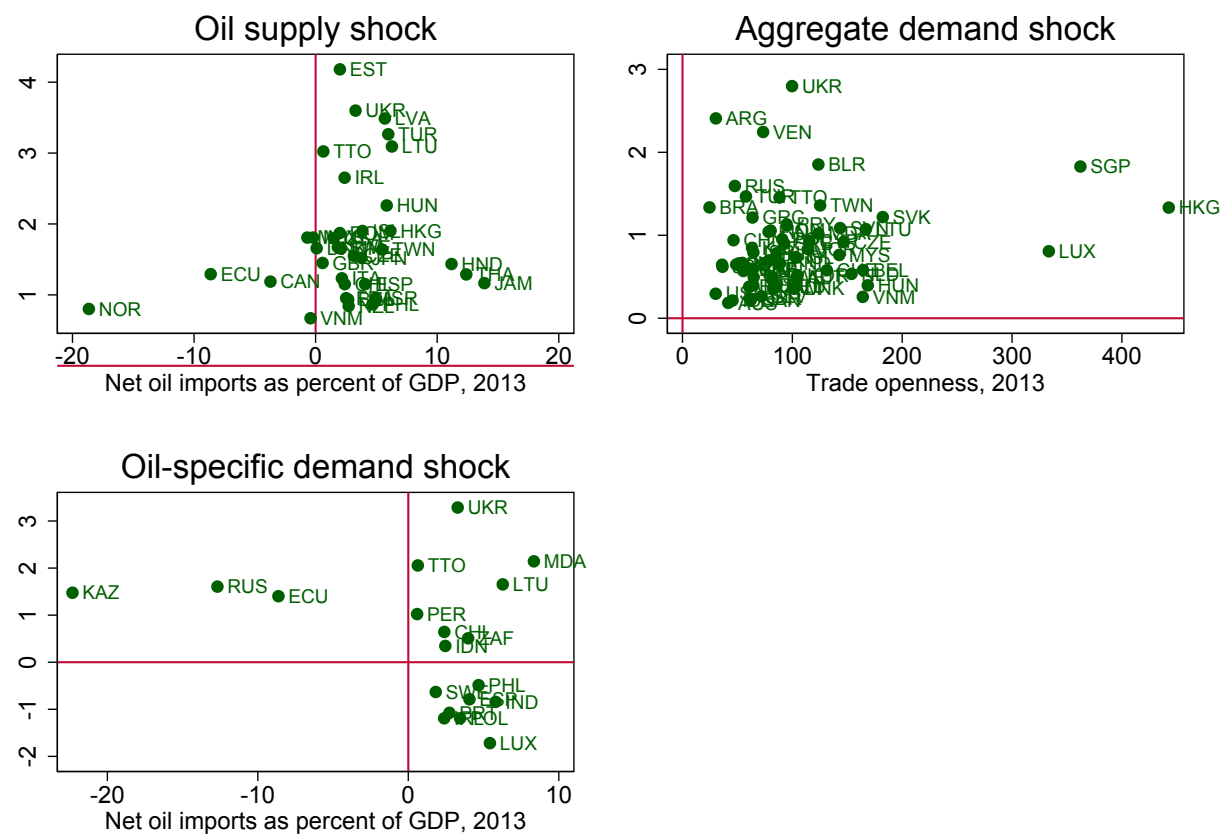

Figure 7: Growth response to world oil market shocks. Each chart displays only those results for which the ratio of the cumulative 1-year effect to its standard error is greater than 1.96 . 
In contrast to the other two structural shocks, oil-specific demand shocks have different qualitative effects across countries. Oil exporters benefit from these shocks, although the one-year effect is significant only for three countries (Kazakhstan, Russia, and Ecuador). While it is difficult to draw conclusions from such a small set of cases, whether an oil exporter is affected by this shock might be related to the extent of diversification of its overall production base - with more diversified countries being less likely to be affected by oil-specific demand shocks. Most oil importers, on the other hand, are harmed by these unexpected shifts in the demand for oil. However, there is a number of oil importers that gain from them (e.g. Ukraine, Brazil, Peru, Chile), possibly due to the price effects of an overall increase in the precautionary demand for commodities more in general.

To understand the lags with which different shocks affect growth, Figure 8 shows the ratio of the cumulative 1-year response to the cumulative 2-year response. ${ }^{11}$ Relatively few countries show significant one-year and two-year cumulative responses to oil-specific demand shocks. In all of those cases, the effect is phased in relatively slowly, with less than half of the total 2-year effect taking place within the first year. On average, about three-quarters of the effect of oil-supply shocks takes place within the first year, with some countries having longer average lags in their responses. In comparison, aggregate demand shocks take effect significantly faster, reflecting the fact that this shock is transmitted much more directly into domestic economies. In many cases there is an over-reaction that is attenuated over the second year. The relative speed at which oil supply and world demand shocks set in is important when interpreting the counterfactual simulations of the following section. In particular, the negative shocks to demand that took place since mid2014 quickly affected individual countries, whereas the benefits from higher than expected oil supply might have taken time to set in (using a different methodology, Mohaddes and Pesaran (2016b) arrive at similar conclusions). This interpretation must, however, be taken with caution as the relative speed at which (in on average) shocks set in appears sensitive to the exclusion restrictions used for identification (see footnote 5).

Table 1 presents the results from pooled OLS regressions for net oil importers and net oil exporters. ${ }^{12}$ Point estimates of two country groups are relatively similar. ${ }^{13}$ The main difference is in the response to oil-specific demand shocks. While these shocks have, on average, negative growth effects on oil importers, oil exporters tend to benefit during the first year (the negative 2-year cumulative effect is not statistically significant).

\footnotetext{
${ }^{11}$ For many countries the oil-specific shocks have significant effect in the first year, but no significant effect in the two years. These countries are not depicted in this Figure.

${ }^{12}$ Given that shocks are orthogonal to country-level variables by construction, pooled OLS is a consistent estimator for the effects of the three shocks. This has been confirmed in separate regressions including fixed effects, not reported here.

${ }^{13}$ Being a larger group, the oil importers regressions are estimated much more precisely.
} 

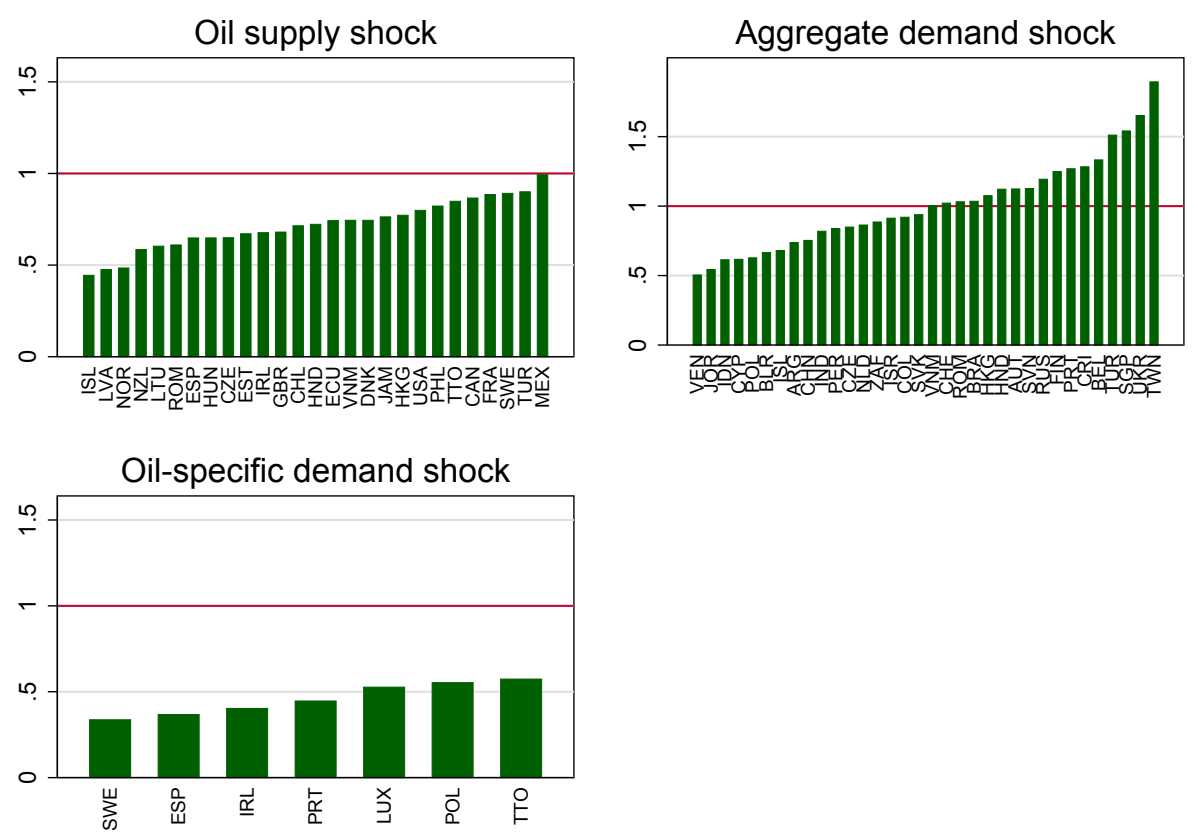

Figure 8: Ratio of 1-year to 2-year cumulative response. Each chart displays only those results for which the ratios of the cumulative 1-year and 2-year effects to their standard errors are greater than 1.96.

\section{Estimation of Counterfactual Growth}

The estimates of the previous sections can be used to disentangle the effect that the recent oil price decline has had on growth. In particular, estimates from country-level growth regressions can be combined with the estimated series of structural shocks driving down the oil price. We are thus able provide estimated counterfactual yearly 2014 and 2015 GDP growth when shocks taking place from July 2014 onwards are turned off. We choose to study the post-June 2014 period since it covers the two recent large oil price drops: the first one in the summer of 2014, and the second one in the fall of 2015. Our methodology can of course be applied to study any other time period. For example, one might consider the second half of 2015 to isolate the outcome of the 2015 oil price drop and eliminate the base effect in counterfactual 2015 growth that is present in our analysis below.

To put the exercise in context, Figure 9 presents the historical and counterfactual oil price in US dollars in the absence of all post-June 2014 shocks. To calculate the latter we set all structural shocks after June 2014 to zero and use the structural VAR (eq. (1)) to calculate the implied real oil price for June 2014 - December 2015. To make the resulting series comparable to the historical nominal oil price series, we multiply the calculated real 
Table 1: Growth Effect of Oil Shocks

\begin{tabular}{lccc}
\hline & & Oil importers & Oil exporters \\
\hline Oil supply & Year 1 & 6.13 & 6.22 \\
& & $(0.55)$ & $(1.36)$ \\
& Year 2 & 8.47 & 8.72 \\
& & $(0.75)$ & $(1.82)$ \\
\hline Aggregate demand & Year 1 & 3.89 & 4.53 \\
& & $(0.20)$ & $(0.52)$ \\
& Year 2 & 3.03 & 4.99 \\
& & $(0.28)$ & $(0.75)$ \\
\hline Oil-specific demand & Year 1 & -0.02 & 1.58 \\
& & $(0.36)$ & $(1.26)$ \\
& Year 2 & -2.92 & -1.68 \\
& & $(0.52)$ & $(1.67)$ \\
\hline & $\mathrm{N}$ & 3,448 & 640 \\
\hline
\end{tabular}

Notes: Results from pooled OLS. Countries classified as oil importers (exporters) are those with negative (positive) net oil imports in 2013, according to April 2016 WEO data.

price by the actual CPI index. ${ }^{14}$.

As Figure 9 shows, if there were no structural shocks after the first half of 2014, the nominal oil price would have stayed on a level of around US\$100 per barrel. Note, however, that it would be incorrect to interpret our counterfactual estimates simply as the growth rates that would have been observed if the oil price had stayed on the level of US\$100. Our exercise goes, in fact, beyond that. While different combinations of structural shocks are consistent with an oil price of US\$100, we work under the assumption that this countefactual price comes out from a very specific combination of structural shocks namely, shocks identical to zero from July 2014 onwards.

To obtain counterfactual growth rates, we calculate fitted values of quarterly growth by plugging in the counterfactual shock series into estimated eq. (2). Specifically, define counterfactual shock series as follows:

$$
\tilde{\zeta}_{\tilde{j} t}= \begin{cases}\hat{\zeta}_{j t} & \text { if } \mathrm{t} \leq 2014 \mathrm{q} 2 \\ \hat{\zeta}_{j t} & \text { if } \mathrm{t}>2014 \mathrm{q} 2 \text { and } j \neq \tilde{j} \\ 0 & \text { if } \mathrm{t}>2014 \mathrm{q} 2 \text { and } j=\tilde{j}\end{cases}
$$

where $\hat{\zeta}_{j t}$ for $j=1,2,3$ are the previously estimated quarterly structural shocks. In words, $\tilde{\zeta}_{\tilde{j} t}$ are structural shocks series in which shock $\tilde{j}=1,2,3$ is "turned off" - that is, set to

\footnotetext{
${ }^{14}$ The reason that the simulated nominal oil price in Figure 9 is not smooth (as one would expect from the predictions of a deterministic autoregressive process) is that it uses the actual US CPI index.
} 


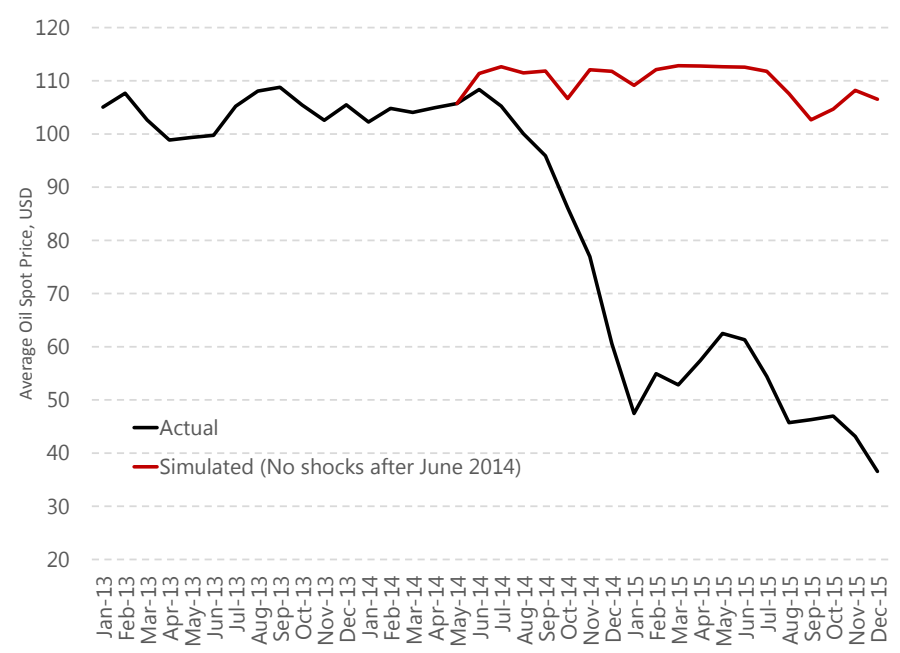

Figure 9: Actual and implied counterfactual oil price.

zero - after 2014q2. To calculate counterfactual quarterly growth series in the absence of shock $\tilde{j}, \Delta \hat{y}_{\tilde{j} t}$, we next calculate fitted values using eq. (2):

$$
\Delta \hat{y}_{\tilde{j} t}=\hat{\alpha}_{\tilde{j}}+\sum_{i=0}^{8} \hat{\phi}_{\tilde{j} i} \tilde{\zeta}_{\tilde{j} t-i}+\hat{u}_{\tilde{j} t}
$$

where $\hat{\alpha}_{j}, \hat{\phi}_{j i}$ are estimated coefficients, $\hat{u}_{j t}$ are estimated residuals that summarize all other factors that affect output other than structural shock $j$ and $\tilde{\zeta}_{j t}$ are counterfactual shock series as defined in Equation (3) above. Using these counterfactual quarterly growth series we calculate implied yearly GDP levels for 2014 and 2015 and then implied yearly growth levels.

Tables 2 and 3 present the results of the exercise for 2014 and 2015 growth, respectively. The first column of Table 3 presents the counterfactual 2015 growth rate in the absence of oil supply shocks after 2014q2 (but with all other shocks as in the data). For example, for the United Kingdom, this growth rate is of 1.92 percent, which is lower than the actual growth rate in 2015 (2.25 percent, see last column of Table 3 ). This implies that oil supply shocks had a small positive effect on the UK economy and contributed around 0.3 percent to 2015 output growth. On the other hand, the UK counterfactual 2015 growth rate in the absence of aggregate demand shocks after 2014q2 (but with all other shocks as in the data), presented in the second column in 3, is 2.61 percent, which is higher than the actual 2015 growth rate. This means that even though aggregate demand contributed to a decrease in the oil price in 2015 (see Figure 4), the overall effect on the UK economy was negative (around -0.4 percent in annual growth terms). Similarly, oil demand shock 
contributed positively (0.2 percent in growth terms, see third column of Table 3 ). Finally, the fourth column presents the counterfactual growth if all three structural shocks are turned off after $2014 \mathrm{q} 2$ and, therefore, the difference between the actual growth and the fourth column represents the overall effect of oil price movements on growth. ${ }^{15}$ Table 2 is organized in exactly the same way.

Table 4 presents summary of GDP growth gains, defined as the difference between actual and counterfactual growth (see Tables 2 and 3) by countries' level of development, type and region. Specifically, we report the results for our sample (92.8 percent of world GDP), for advanced (AEs) and emerging and developing countries (EMDEs) as well as oil exporting and oil importing countries. ${ }^{16}$ Finally, we report the estimates for the Latin America and Caribbean region. For each country group we report median gain and GDPweighted mean within the corresponding group.

Table 4 shows that, in 2015, positive oil supply shocks and better expectations about the oil market boosted global growth by about 0.6 percentage points (p.p.) but this was more than offset by a decline in aggregate demand equivalent to about -0.8 p.p. The positive effect consists of around 0.2 p.p. gain from oil supply increase and about 0.4 p.p. from better expectations in the oil market (see the first two lines of Table 4). The overall effect on AEs in 2015 was positive - between 0.3 and 0.6 p.p. - while on EMDEs it was strongly negative - between -1.1 and -1.5 p.p. (see Table 4). Both groups benefited from the oil price decline due to higher oil supply. However, AEs suffered less from the decline in aggregate demand - estimated effect -0.5 p.p. (median) to -0.7 p.p. (GDPweighted mean) in 2015 - than EMDEs - estimated effect -1 p.p. (median) to -1.3 p.p. (GDP-weighted mean) in 2015.

As expected, compared to oil importers, oil exporters benefited more from oil supply shocks, but suffered more from the decline in aggregate demand and better expectations about the oil market. Oil exporters benefited more from increased oil supply by definition: most of the increase in the oil supply took place in countries that were already exporting oil. Both types of countries suffered from the decline in aggregate demand in 2015, but oil exporters were hurt more as they tend to have larger oil-related BOP flows and be more open than oil-importers. The oil specific shock benefited (hurt) oil importers (exporters) significantly in 2015 as the shale revolution lowered the value of future oil reserves.

Lastly, the median country in Latin America and the Caribbean benefited from in-

${ }^{15}$ The effect of all three shocks (difference between the actual growth and the fourth column) is approximately equal to the sum of individual effects of each shock. The relationship is not exact due to non-linearities that arise because of the base effect when calculating 2015 growth.

${ }^{16} \mathrm{~A}$ country is defined as an oil exporters if, in 2013 (i.e. before the period under consideration), oil exports are greater than oil imports. 

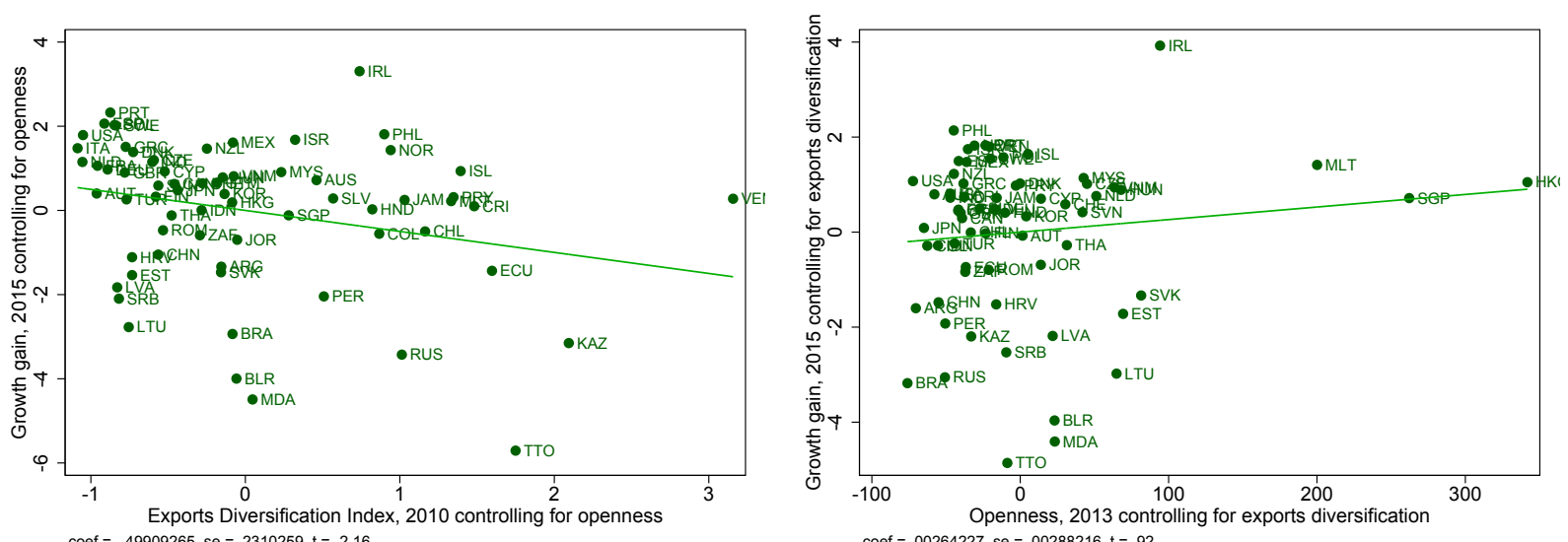

Figure 10: Partial regressions of 2015 net growth gains on export diversification (controlling for openness) and openness (controlling for export diversification).

creases in oil supply (0.3 p.p) while weak global and oil demand shocks more than offset this gain, reducing growth by 0.7 and 0.2 p.p. respectively resulting in overall loss of 0.6 percent growth in 2015.

To shed further light on the heterogeneity of country responses to the decline in the price of oil, we look at how net gains from the oil price shocks relate to characteristics beyond a country's region and net oil exports status. Two likely candidate determinants of a country's response are its degree of openness, and its degree of export diversification. A country's openness makes it highly sensitive to swings in world demand, something that was confirmed by the country-level growth regressions above. More diversified exports offer, among other things, an insurance against shocks that may have disproportionately larger effects on certain sectors, such as industrial commodities.

Figure 10 shows the partial association between 2015 net growth gains and export diversification (left panel) and openness (right panel). ${ }^{17}$ Higher diversification of exports (associated with a lower export diversification index) is associated with a smaller effect of oil price movements on economic activity. That is, less diversified economies suffered more as a result of the oil price decline, with the association being significant at a $5 \%$ level. ${ }^{18}$

\footnotetext{
${ }^{17}$ Being partial associations means that the association between net growth gains and openness controls for diversification, and vice versa. In other words the charts correspond to the graphical representation of partial regressions of output gain on exports diversification and openness respectively. Conditionality also explains negative values on the $\mathrm{x}$-axis.

The export diversification index is a Theil index constructed from data for 12 sectors and 187 countries (see Papageorgiou and Spatafora (2012); the index is available at https://www.imf.org/external/np/res/dfidimf/diversification.htm). Openness is measure as the ratio of sum of exports and imports of goods and services to GDP.

${ }^{18}$ Figure 10 excludes the estimates for Ukraine, for which we find very large net losses from the oil price shocks (see Table 3) that may be more reflective of idiosyncratic circumstances. If one includes Ukraine in the scatterplot, the level of linear statistical significance decreases. Despite this, Ukraine's story is consistent with the above intuition: the overall estimated effect of the oil price decline in 2015
} 
Table 2: Counterfactual 2014 GDP growth rates in percent.

Each column presents counterfactual growth when one or all of the shocks is absent after June 2014

\begin{tabular}{|c|c|c|c|c|c|}
\hline & No Oil Supply & No Aggregate Demand & No Oil Demand & No shocks & Actual growth \\
\hline United States & 2.24 & 2.40 & 2.53 & 2.31 & 2.43 \\
\hline United Kingdom & 2.68 & 2.81 & 2.95 & 2.73 & 2.85 \\
\hline Austria & 0.44 & 0.42 & 0.84 & 0.74 & 0.47 \\
\hline Belgium & 1.25 & 1.29 & 1.58 & 1.43 & 1.35 \\
\hline Denmark & 1.12 & 1.23 & 1.56 & 1.38 & 1.26 \\
\hline France & 0.08 & 0.12 & 0.44 & 0.29 & 0.17 \\
\hline Germany & 1.55 & 1.51 & 1.74 & 1.64 & 1.58 \\
\hline Italy & -0.36 & -0.35 & -0.10 & -0.28 & -0.27 \\
\hline Luxembourg & 3.88 & 4.03 & 4.19 & 3.93 & 4.08 \\
\hline Netherlands & 0.97 & 0.95 & 1.04 & 0.94 & 1.01 \\
\hline Norway & 2.10 & 2.21 & 1.92 & 1.81 & 2.21 \\
\hline Sweden & 2.22 & 2.32 & 2.56 & 2.33 & 2.38 \\
\hline Switzerland & 1.86 & 1.83 & 2.06 & 1.97 & 1.89 \\
\hline Canada & 2.35 & 2.47 & 2.75 & 2.63 & 2.47 \\
\hline Japan & -0.27 & -0.24 & 0.10 & -0.19 & -0.11 \\
\hline Finland & -0.82 & -0.85 & -0.25 & -0.53 & -0.70 \\
\hline Greece & 0.60 & 0.56 & 0.14 & -0.13 & 0.72 \\
\hline Iceland & 1.65 & 1.74 & 2.12 & 1.76 & 1.88 \\
\hline Ireland & 4.95 & 5.14 & 5.29 & 4.97 & 5.21 \\
\hline Malta & 4.14 & 4.03 & 3.98 & 4.03 & 4.06 \\
\hline Portugal & 0.86 & 0.80 & 0.76 & 0.61 & 0.91 \\
\hline Spain & 1.27 & 1.29 & 1.21 & 1.05 & 1.36 \\
\hline Turkey & 2.56 & 2.61 & 3.88 & 3.22 & 2.91 \\
\hline Australia & 2.55 & 2.60 & 2.67 & 2.59 & 2.62 \\
\hline New Zealand & 2.82 & 2.93 & 2.72 & 2.51 & 2.98 \\
\hline South Africa & 1.54 & 1.51 & 2.00 & 1.96 & 1.55 \\
\hline Argentina & 0.32 & 0.25 & 0.68 & 0.35 & 0.45 \\
\hline Brazil & 0.13 & -0.03 & 1.32 & 1.22 & 0.10 \\
\hline Chile & 1.80 & 1.77 & 2.31 & 2.21 & 1.83 \\
\hline Colombia & 4.33 & 4.31 & 4.61 & 4.49 & 4.39 \\
\hline Costa Rica & 2.95 & 2.90 & 3.11 & 2.99 & 2.98 \\
\hline Ecuador & 3.95 & 4.00 & 4.78 & 4.74 & 3.99 \\
\hline El Salvador & 1.38 & 1.37 & 1.56 & 1.47 & 1.42 \\
\hline Guatemala & 4.17 & 4.14 & 4.16 & 4.14 & 4.16 \\
\hline Honduras & 2.96 & 3.06 & 3.25 & 3.10 & 3.09 \\
\hline Mexico & 2.09 & 2.21 & 2.44 & 2.23 & 2.25 \\
\hline Paraguay & 4.53 & 4.35 & 4.50 & 4.20 & 4.59 \\
\hline Peru & 2.53 & 2.41 & 2.91 & 2.95 & 2.45 \\
\hline Venezuela & -4.00 & -4.04 & -3.66 & -3.95 & -3.87 \\
\hline Jamaica & 0.39 & 0.47 & 0.27 & 0.07 & 0.53 \\
\hline Trinidad and Tobago & 1.18 & 1.28 & 1.69 & 1.18 & 1.49 \\
\hline Cyprus & -2.52 & -2.58 & -2.22 & -2.33 & -2.50 \\
\hline Israel & 2.54 & 2.58 & 2.99 & 2.79 & 2.66 \\
\hline Jordan & 3.19 & 3.00 & 3.25 & 3.26 & 3.09 \\
\hline Taiwan Province of China & 3.69 & 3.84 & 4.93 & 4.55 & 3.96 \\
\hline Hong Kong SAR & 2.42 & 2.44 & 3.01 & 2.58 & 2.65 \\
\hline India & 7.22 & 7.16 & 7.04 & 6.95 & 7.24 \\
\hline Indonesia & 5.10 & 4.99 & 5.18 & 5.23 & 5.02 \\
\hline Korea & 3.16 & 3.26 & 3.71 & 3.52 & 3.31 \\
\hline Malaysia & 5.76 & 5.86 & 6.08 & 5.72 & 5.99 \\
\hline Philippines & 6.07 & 6.07 & 5.96 & 5.84 & 6.13 \\
\hline Singapore & 3.05 & 3.04 & 4.01 & 3.53 & 3.29 \\
\hline Thailand & 0.72 & 0.85 & 1.01 & 0.92 & 0.83 \\
\hline Vietnam & 5.86 & 5.87 & 5.97 & 5.80 & 5.95 \\
\hline Belarus & 1.48 & 1.30 & 2.19 & 2.10 & 1.44 \\
\hline Kazakhstan & 4.22 & 4.24 & 5.05 & 4.88 & 4.32 \\
\hline Moldova & 4.62 & 4.49 & 4.87 & 4.72 & 4.63 \\
\hline Russia & 0.34 & 0.39 & 1.65 & 1.35 & 0.52 \\
\hline China & 7.30 & 7.15 & 7.66 & 7.60 & 7.25 \\
\hline Ukraine & -6.86 & -6.88 & -4.43 & -5.06 & -6.55 \\
\hline Czech Republic & 1.91 & 1.89 & 1.99 & 1.83 & 1.98 \\
\hline Slovak Republic & 2.55 & 2.35 & 2.97 & 2.83 & 2.52 \\
\hline Estonia & 2.55 & 2.88 & 3.73 & 3.37 & 2.90 \\
\hline Latvia & 2.23 & 2.45 & 2.92 & 2.65 & 2.47 \\
\hline Serbia & -1.97 & -1.89 & -1.09 & -1.41 & -1.77 \\
\hline Hungary & 3.45 & 3.54 & 3.63 & 3.39 & 3.62 \\
\hline Lithuania & 2.90 & 2.93 & 3.85 & 3.54 & 3.07 \\
\hline Croatia & -0.37 & -0.49 & -0.50 & -0.62 & -0.38 \\
\hline Slovenia & 2.79 & 2.74 & 2.99 & 2.82 & 2.85 \\
\hline Poland & 3.28 & 3.20 & 2.77 & 2.63 & 3.31 \\
\hline Romania & 2.82 & 2.73 & 2.84 & 2.64 & 2.88 \\
\hline
\end{tabular}

CInternational Monetary Fund. Not for Redistribution 
Table 3: Counterfactual 2015 gdp growth rates in percent.

Each column presents counterfactual growth when one or all of the shocks is absent after June 2014

\begin{tabular}{|c|c|c|c|c|c|}
\hline & No Oil Supply & No Aggregate Demand & No Oil Demand & No shocks & Actual growth \\
\hline United States & 2.06 & 2.79 & 1.45 & 1.44 & 2.43 \\
\hline United Kingdom & 1.92 & 2.61 & 2.02 & 2.06 & 2.25 \\
\hline Austria & 0.66 & 1.34 & 0.66 & 1.02 & 0.82 \\
\hline Belgium & 1.19 & 2.06 & 0.34 & 0.85 & 1.37 \\
\hline Denmark & 0.80 & 1.47 & 0.43 & 0.38 & 1.16 \\
\hline France & 0.92 & 1.62 & 0.52 & 0.79 & 1.14 \\
\hline Germany & 1.34 & 1.64 & 1.05 & 1.13 & 1.45 \\
\hline Italy & 0.37 & 1.25 & -0.44 & -0.10 & 0.64 \\
\hline Luxembourg & 4.33 & 5.94 & 0.70 & 1.95 & 4.51 \\
\hline Netherlands & 1.73 & 2.38 & 0.89 & 1.20 & 1.90 \\
\hline Norway & 1.46 & 1.90 & 0.86 & 0.92 & 1.65 \\
\hline Sweden & 3.49 & 4.40 & 2.24 & 2.47 & 3.83 \\
\hline Switzerland & 0.75 & 1.45 & 0.23 & 0.73 & 0.85 \\
\hline Canada & 0.94 & 1.28 & 1.39 & 1.26 & 1.17 \\
\hline Japan & 0.25 & 1.34 & 0.29 & 0.83 & 0.53 \\
\hline Finland & 0.05 & 1.53 & 0.05 & 0.77 & 0.43 \\
\hline Greece & -0.67 & 1.65 & -2.74 & -1.12 & -0.32 \\
\hline Iceland & 3.48 & 5.02 & 3.13 & 3.66 & 3.99 \\
\hline Ireland & 7.19 & 8.26 & 5.08 & 4.87 & 7.83 \\
\hline Malta & 4.76 & 4.66 & 5.12 & 4.73 & 4.90 \\
\hline Portugal & 1.39 & 2.27 & -0.90 & -0.19 & 1.47 \\
\hline Spain & 2.91 & 3.91 & 1.48 & 1.87 & 3.21 \\
\hline Turkey & 3.09 & 5.89 & 2.49 & 4.14 & 3.67 \\
\hline Australia & 2.45 & 2.73 & 2.31 & 2.53 & 2.48 \\
\hline New Zealand & 3.22 & 3.77 & 2.47 & 2.66 & 3.40 \\
\hline South Africa & 1.13 & 1.95 & 2.07 & 2.58 & 1.28 \\
\hline Argentina & 0.77 & 4.39 & 0.58 & 3.34 & 1.20 \\
\hline Brazil & -3.74 & -2.18 & -1.89 & -0.09 & -3.85 \\
\hline Chile & 1.80 & 2.58 & 3.03 & 3.28 & 2.07 \\
\hline Colombia & 3.05 & 4.06 & 3.47 & 4.42 & 3.08 \\
\hline Costa Rica & 3.73 & 4.47 & 3.79 & 4.41 & 3.79 \\
\hline Ecuador & -0.14 & 0.05 & 2.72 & 2.31 & 0.16 \\
\hline El Salvador & 2.28 & 2.77 & 2.71 & 2.85 & 2.45 \\
\hline Guatemala & 4.13 & 4.43 & 3.96 & 4.22 & 4.15 \\
\hline Honduras & 3.40 & 4.35 & 3.80 & 4.26 & 3.64 \\
\hline Mexico & 2.21 & 2.76 & 1.77 & 1.64 & 2.55 \\
\hline Paraguay & 3.10 & 4.79 & 2.53 & 3.68 & 3.37 \\
\hline Peru & 3.50 & 3.85 & 5.15 & 6.03 & 3.24 \\
\hline Venezuela & -6.14 & -3.13 & -6.97 & -5.14 & -5.55 \\
\hline Jamaica & 0.67 & 1.52 & 1.02 & 1.34 & 0.93 \\
\hline Trinidad and Tobago & -2.46 & 0.77 & 2.45 & 4.49 & -1.86 \\
\hline Cyprus & 1.40 & 2.44 & 0.55 & 1.23 & 1.59 \\
\hline Israel & 2.70 & 3.85 & 1.01 & 1.87 & 2.84 \\
\hline Jordan & 2.51 & 3.55 & 2.67 & 3.75 & 2.49 \\
\hline Taiwan Province of China & 0.64 & 2.77 & -0.69 & 1.08 & 0.82 \\
\hline Hong Kong SAR & 1.90 & 4.11 & 0.52 & 1.82 & 2.36 \\
\hline India & 7.32 & 8.53 & 5.65 & 6.89 & 7.30 \\
\hline Indonesia & 4.85 & 4.90 & 5.38 & 5.55 & 4.79 \\
\hline Korea & 2.63 & 3.39 & 1.97 & 2.80 & 2.60 \\
\hline Malaysia & 4.69 & 5.93 & 3.82 & 4.53 & 4.95 \\
\hline Philippines & 5.59 & 5.94 & 4.81 & 4.73 & 5.81 \\
\hline Singapore & 1.77 & 4.41 & -0.18 & 2.00 & 2.01 \\
\hline Thailand & 2.64 & 3.48 & 3.00 & 3.46 & 2.83 \\
\hline Vietnam & 6.58 & 7.17 & 6.07 & 6.35 & 6.74 \\
\hline Belarus & -4.00 & -2.09 & -1.07 & 0.64 & -3.90 \\
\hline Kazakhstan & 0.32 & 1.94 & 3.28 & 4.42 & 0.56 \\
\hline Moldova & -0.96 & 0.42 & 3.54 & 4.35 & -0.68 \\
\hline Russia & -3.90 & -1.77 & -0.91 & 0.60 & -3.58 \\
\hline China & 7.08 & 8.30 & 7.22 & 8.74 & 6.93 \\
\hline Ukraine & -10.59 & -6.47 & -3.94 & -1.21 & -9.87 \\
\hline Czech Republic & 3.89 & 5.23 & 3.03 & 3.57 & 4.29 \\
\hline Slovak Republic & 3.44 & 4.85 & 4.34 & 5.44 & 3.60 \\
\hline Estonia & 0.25 & 1.91 & 3.31 & 3.12 & 1.18 \\
\hline Latvia & 1.64 & 3.65 & 4.85 & 4.96 & 2.59 \\
\hline Serbia & 0.57 & 2.01 & 2.06 & 3.36 & 0.64 \\
\hline Hungary & 2.36 & 3.35 & 2.65 & 2.54 & 2.91 \\
\hline Lithuania & 0.76 & 2.56 & 4.65 & 4.79 & 1.59 \\
\hline Croatia & 1.23 & 2.62 & 2.70 & 3.36 & 1.60 \\
\hline Slovenia & 2.25 & 3.71 & 1.72 & 2.49 & 2.59 \\
\hline Poland & 3.55 & 4.67 & 1.19 & 2.21 & 3.60 \\
\hline Romania & 3.30 & 4.83 & 4.21 & 4.87 & 3.74 \\
\hline
\end{tabular}

CInternational Monetary Fund. Not for Redistribution 
Table 4: Gains in growth rates in percent for different subgroups of countries.

\begin{tabular}{|c|c|c|c|c|c|c|c|c|}
\hline & \multicolumn{2}{|c|}{ Oil Supply } & \multicolumn{2}{|c|}{ Total Demand } & \multicolumn{2}{|c|}{ Oil Specific } & \multicolumn{2}{|c|}{ All Shocks } \\
\hline & 2014 & 2015 & 2014 & 2015 & 2014 & 2015 & 2014 & 2015 \\
\hline & \multicolumn{8}{|c|}{ World } \\
\hline Median & 0.10 & 0.23 & 0.08 & -0.80 & -0.18 & 0.38 & -0.01 & -0.20 \\
\hline \multirow[t]{2}{*}{ GDP-weighted mean } & 0.10 & 0.19 & 0.07 & -0.78 & -0.26 & 0.43 & -0.08 & -0.17 \\
\hline & \multicolumn{8}{|c|}{ Advanced Economies } \\
\hline Median & 0.12 & 0.23 & 0.07 & -0.69 & -0.18 & 0.88 & 0.02 & 0.34 \\
\hline \multirow[t]{2}{*}{ GDP-weighted mean } & 0.14 & 0.28 & 0.06 & -0.50 & -0.15 & 0.79 & 0.04 & 0.57 \\
\hline & \multicolumn{8}{|c|}{ Emerging and Developing Economies } \\
\hline Median & 0.06 & 0.24 & 0.09 & -1.00 & -0.19 & -0.27 & -0.07 & -1.17 \\
\hline \multirow[t]{2}{*}{ GDP-weighted mean } & 0.03 & 0.02 & 0.11 & -1.30 & -0.45 & -0.25 & -0.32 & -1.53 \\
\hline & \multicolumn{8}{|c|}{ Oil Exporters } \\
\hline Median & 0.11 & 0.24 & 0.08 & -0.97 & -0.23 & -0.21 & -0.10 & -0.41 \\
\hline \multirow[t]{2}{*}{ GDP-weighted mean } & 0.14 & 0.28 & 0.06 & -0.78 & -0.47 & -0.50 & -0.27 & -1.01 \\
\hline & \multicolumn{8}{|c|}{ Oil Importers } \\
\hline Median & 0.09 & 0.22 & 0.08 & -0.80 & -0.17 & 0.39 & -0.01 & -0.13 \\
\hline \multirow[t]{2}{*}{ GDP-weighted mean } & 0.10 & 0.18 & 0.07 & -0.78 & -0.23 & 0.51 & -0.06 & -0.09 \\
\hline & \multicolumn{8}{|c|}{ Latin America and Caribbean } \\
\hline Median & 0.05 & 0.26 & 0.06 & -0.68 & -0.20 & -0.16 & -0.01 & -0.62 \\
\hline GDP-weighted mean & 0.05 & 0.15 & 0.10 & -1.35 & -0.66 & -0.59 & -0.51 & -1.80 \\
\hline
\end{tabular}

Conditional on the diversification of exports, however, there is no significant association between openness and net gains from the oil price shocks. ${ }^{19}$

\section{Concluding Remarks}

There is, or at least used to be, a presumption that low oil prices must be good for growth. In this sense, the recent oil price slump did not live up to expectations. This paper contributes to the debate by providing systematic evidence for a wide range of countries on the growth effect of shocks driving the oil price. Our estimates show that the configuration of shocks behind the sharp decline in oil prices since 2014 was, on net, unfavorable for growth. Positive oil supply surprises had a positive effect on growth, but low oil prices were largely symptomatic of a weak global economy demanding less commodities in general, and oil in particular. A look at the possible determinants of the heterogeneous gains from the oil price shocks underscores the importance of diversification, rather than low levels of openness, in shielding against negative shocks to the world economy.

was negative and large (8.7 p.p) and exports diversification was low (11 percentile out of 173 countries).

${ }^{19}$ One might think that the outcome is driven by large oil exporters (e.g., RUS) or countries with questionable quality data (e.g., VEN). In fact the results become even more pronounced if countries such as RUS or VEN are excluded from the sample: coefficient on the diversification index becomes more significant, while the coefficent on openness does not. 


\section{References}

Aastveit, Knut Are, Hilde C. Bjørnland, and Leif Anders Thorsrud. 2015. "What Drives Oil Prices? Emerging Versus Developed Economies." Journal of Applied Econometrics, 30(7): 1013-1028.

Arezki, R., and O. Blanchard. 2014. "Seven Questions About the Recent Oil Price Slump." iMFdirect blog.

Aslam, Aqib, Samya Beidas-Strom, Rudolfs Bems, Oya Celasun, Sinem Kikic Celik, and Zsoka Koczan. 2016. "Trading on Their Terms? Commodity Exporters in the Aftermath of the Commodity Boom." IMF Working Paper, 16/27.

Baffes, John, M.A. Kose, Franziska Ohnsorge, and Marc Stocker. 2015. "The Great Plunge in Oil Prices: Causes, Consequences, and Policy Responses." World Bank Policy Research Note.

Barsky, Robert B., and Lutz Kilian. 2004. "Oil and the Macroeconomy Since the 1970s." Journal of Economic Perspectives, 18(4): 115-134.

Beidas-Strom, Samia, and Andrea Pescatori. 2014. "Oil Price Volatility and the Role of Speculation." IMF Working Paper, 14/218: 1-33.

Bernanke, B., M. Gertler, and M. Watson. 1997. "Systematic Monetary Policy and the Effect of Oil Price Shocks." Brookings Papers on Economic Activity, 28(1): 91-157.

Blanchard, O., and J. Gali. 2007. "The Macroeconomic Effects of Oil Price Shocks: Why are the 2000s so different from the 1970s?" International Dimensions of Monetary Policy, 373-421.

Cashin, Paul, Kamiar Mohaddes, Maziar Raissi, and Mehdi Raissi. 2012. "The Differential Effects of Oil Demand and Supply Shocks on the Global Economy." Cambridge Working Papers in Economics, CWPE(1249).

Erten, Bilge, and Jose Antonio Ocampo. 2013. "Super Cycles of Commodity Prices Since the Mid-Nineteenth Centuryl." World Development, 44: 14-30.

Gruss, Bertrand. 2014. "After the BoomCommodity Prices and Economic Growth in Latin America and the Caribbean." IMF Working Paper, 14/154.

Hamilton, J.D. 2003. "What Is an Oil Shock?" Journal of Economics, 113(2): 363-398. 
Husain, Aasim M., Rabah Arezki, Peter Breuer, Vikram Haksar, Thomas

Helbling, Paulo Medas, and Martin Sommer. 2015. "Global Implications of Lower

Oil Prices." IMF Staff Discussion Note, 15: 1-41.

IMF. 2015a. "External Sector Report." International Monetary Fund.

IMF. 2015b. "World Economic Outlook." International Monetary Fund, April.

IMF. 2016. "World Economic Outlook." International Monetary Fund, April.

Jacks, David S. 2013. "From Boost to Bust: A Typology of Real Commodity Prices in the Long Run." NBER Working Paper, 18874: 1-86.

Kilian, L. 2009. "Not All Oil Price Shocks Are Alike: Disentangling Demand and Supply Shocks in the Crude Oil Market." American Economic Review, 99(3): 1053-1069.

Kilian, L., and Daniel. P. Murphy. 2014. "The Role of Inventories and Speculative Trading in the Global Market for Crude Oil." Journal of Applied Econometrics, 29: 454478.

Kilian, Lutz. 2014. "Oil Price Shocks: Causes and Consequences." Annual Review of Resource Economics, 6: 133-154.

Kilian, Lutz. 2016. "The Impact of the Shale Oil Revolution in U.S. Oil and Gasoline Prices." mimeo.

Mohaddes, Kamiar, and M. Hashem Pesaran. 2016a. "Country-specific oil supply shocks and the global economy: A counterfactual analysis." Energy Economics, 59: 382399.

Mohaddes, Kamiar, and M. Hashem Pesaran. 2016b. "Oil Prices and the Global Economy: Is it Different this Time Around?" USC-INET Research Paper, 16: 1-28.

Obstfeld, Maurice, Gian Maria Milesi-Ferretti, and Rabah Arezki. 2016. "Oil Prices and the Global Economy: It's Complicated." iMFdirect Blog, March.

Papageorgiou, Chris, and Nikola Spatafora. 2012. "Economic Diversification in LICs: Stylized Facts and Macroeconomic Implications." IMF Staff Discussion Note, $12 / 13$. 